Юрчик Г. М., к.е.н., доцент, Човпило М. М., студент (Національний університет водного господарства та природокористування, м. Рівне)

\title{
ТЕНДЕНЦІї ТА НАПРЯМИ ПОДОЛАННЯ БЕЗРОБІТТЯ В УКРАЇНІ
}

Досліджено тенденції безробіття в Україні. Проведено аналіз залучення безробітних до активних та пасивних програм в системі Державної служби зайнятості. Доведено вплив макроекономічних факторів на безробіття населення. Визначено основні проблеми та напрями зниження безробіття в Україні.

Ключові слова: безробіття, рівень безробіття, допомога по безробіттю.

Вступ. Безробіття $\epsilon$ невід'ємною складовою ринкової економіки, що виникає як результат взаємодії між попитом на працю та її пропозицією. В свою чергу, попит та пропозиція на ринку праці формується під впливом низки чинників, серед яких: структурні зрушення в економіці; темпи економічного розвитку; науково-технічний прогрес; співвідношення цін на фактори виробництва; сезонні коливання виробництва; сукупний споживчий попит; інфляція; трудове законодавство; демографічні тенденції; професійно-кваліфікаційні характеристики населення тощо [1]. Перераховані соціально-економічні фактори визначають кон'юнктуру ринку праці, яка у разі превалювання несприятливо впливу стає трудонадлишковою. Безробіття, як результат перевищення пропозиції праці над попитом на неї, в незначних масштабах позитивно впливає на функціонування ринку праці, адже задіює механізм конкуренції, а відтак - сприяє зростанню професійно-кваліфікаційного рівня економічно-активного населення та продуктивності праці. Водночас, високий рівень безробіття, що перевищує його природний рівень, становить загрозу соціальноекономічному розвитку та безпеці.

Аналіз останніх досліджень. Дослідженню проблеми безробіття присвячені праці таких вчених, як Д. Богиня, В. Геєць, В. Герасимчук, О. Грішнова, С. Дорогунцов, Е. Лібанова, Г. Лук'янова, В. Онікієнко, Ю. Маршавін, Л. Ярової та ін. Попри наявність значного наукового доробку у відповідній сфері, все ж значний рівень безробіття в Україні потребує безперервного моніторингу тенденцій на напрямів подолання безробіття на національному ринку праці.

Постановка завдання. Метою даної статті $\epsilon$ комплексне дослідження тенденцій безробіття та напрямів його подолання в Україні 3 
метою виявлення основних проблем та обґрунтування пропозицій у відповідній сфері.

Наукові результати. Закон України «Про зайнятість населення» визначає сутність безробіття як соціально-економічне явище, за якого частина осіб не має змоги реалізувати своє право на працю та отримання заробітної плати (винагороди) як джерела існування. При цьому національне законодавство при ідентифікації безробітного населення орієнтоване на підхід Міжнародної організації праці (МОП) та факт реєстрації відповідного статусу особи в Державній службі зайнятості (табл. 1).

Таблиця 1

Законодавче визначення категорії «безробітний» в Україні [2]

\begin{tabular}{|c|c|}
\hline \multicolumn{2}{|c|}{ Законодавче визначення категорії } \\
\hline безробітний (підхід МОП) & зареєстрований безробітний \\
\hline $\begin{array}{l}\text { особа віком від } 15 \text { до } 70 \text { років, } \\
\text { яка через відсутність роботи } \\
\text { не має заробітку або інших пе- } \\
\text { редбачених законодавством } \\
\text { доходів як джерела існування, } \\
\text { готова та здатна приступити } \\
\text { до роботи. }\end{array}$ & $\begin{array}{l}\text { особа працездатного віку, яка зареєст- } \\
\text { рована в територіальному органі цент- } \\
\text { рального органу виконавчої влади, що } \\
\text { реалізує державну політику у сфері } \\
\text { зайнятості населення та трудової мігра- } \\
\text { ції, як безробітна і готова та здатна при- } \\
\text { ступити до роботи. }\end{array}$ \\
\hline
\end{tabular}

Аналіз тенденцій безробіття в Україні (рис. 1) свідчить, що протягом 2013-2017 рр. рівень безробіття за методикою МОП в Україні суттєво збільшився та сягнув 9,5\%.

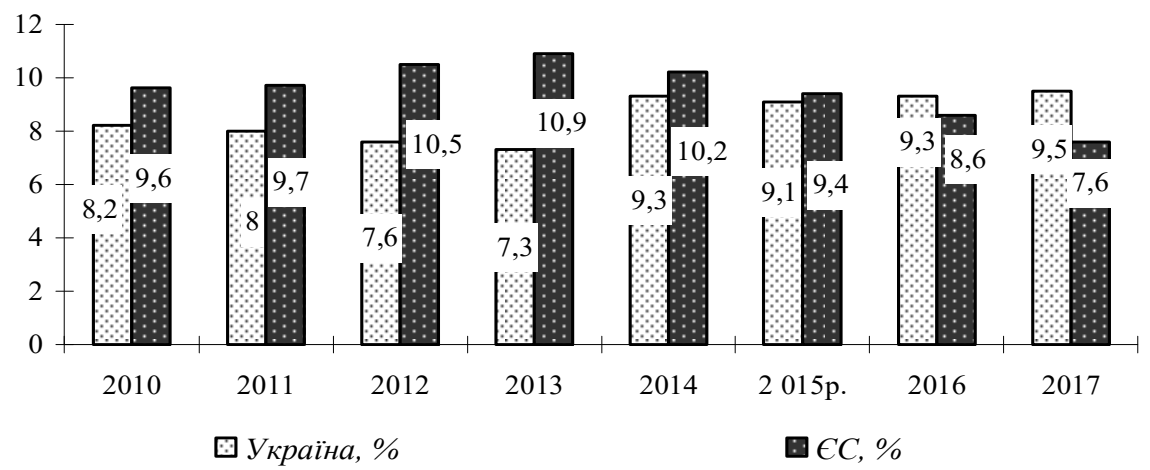

Рис. 1. Динаміка рівня безробіття (МОП) в Україні та ЄС, 2010-2017 pp. [3; 4]

Показово, що протягом 2010-2014 рр. частка безробітних в Україні порівняно з ЄС була суттєво меншою. Водночас, соціально- 
економічні негаразди та політична нестабільність останніх років зумовила зростання рівня безробіття, який з 2016 р. перевищив відповідний показник в ЄС (9,5\% проти 7,6\% у 2017 р.).

В той же час, рівень зареєстрованого безробіття в Україні $€$ суттєво нижчим порівно з рівнем безробіття за методикою МОП (рис. 2). Така відмінність в показниках безробіття пояснюється тим, що лише кожен п'ятий-шостий реальний безробітний підтверджує свій статус офіційно в Державній службі зайнятості (ДСЗ).

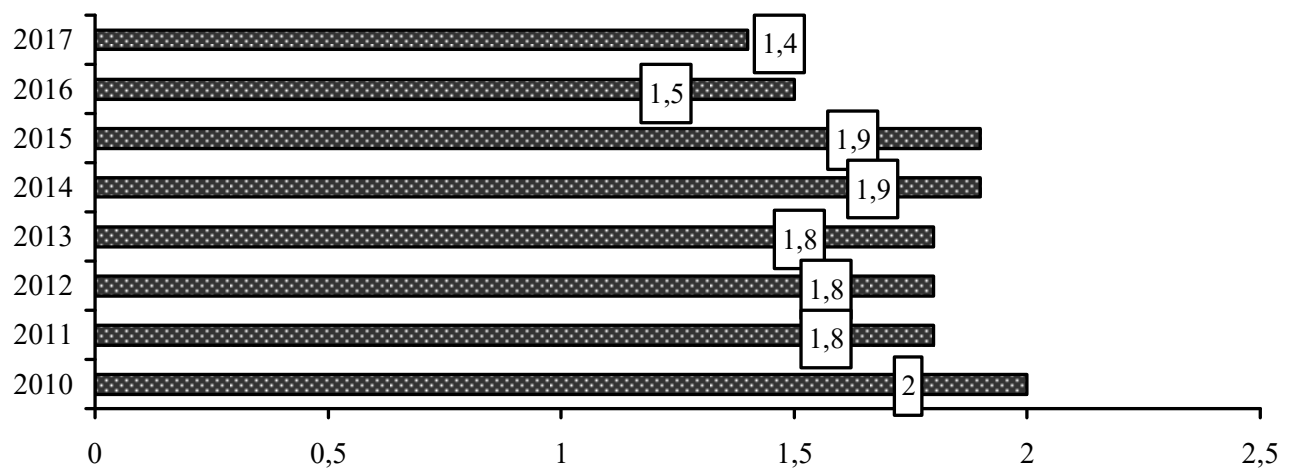

Рис. 2. Динаміка рівня зареєстрованого безробіття в Україні, 2010-2017 pp. [3]

Показово, що рівень зареєстрованого безробіття, на відміну від рівня безробіття за методикою МОП, знижується. Це в значній мірі обумовлено адміністративними чинниками, адже отримавши відповідний статус в центрі зайнятості, безробітний зобов'язаний періодично підтверджувати його незмінність, виконувати рекомендації щодо працевлаштування. В той же час, чинник реєстрації безробіття з мотивів отримання допомоги по безробіттю (ДПБ), на сьогоднішній день в значній мірі нівелюється з огляду на надто низький розмір відповідних виплат (розглянуто нижче).

На сьогоднішній день в цілях подолання безробіття ДСЗ реалізує комплекс заходів, які можна умовно поділити на активні та пасивні (рис. 3).

Принципова відмінність між активними та пасивними інструментами подолання безробіття полягає в тому, що перші спрямовані на активізацію зусиль, підвищення конкурентоспроможності безробітних на ринку праці, а пасивної - на компенсацію втраченого трудового доходу в період незайнятості. Безумовно, вищий рівень як економічної, так і соціальної ефективності мають інструменти активної політики, оскільки в основі їх реалізації покладено принцип надання не «риби», а «вудочки», що обумовлює соціальну підтримку безробітних за умови їх трудової активності. 


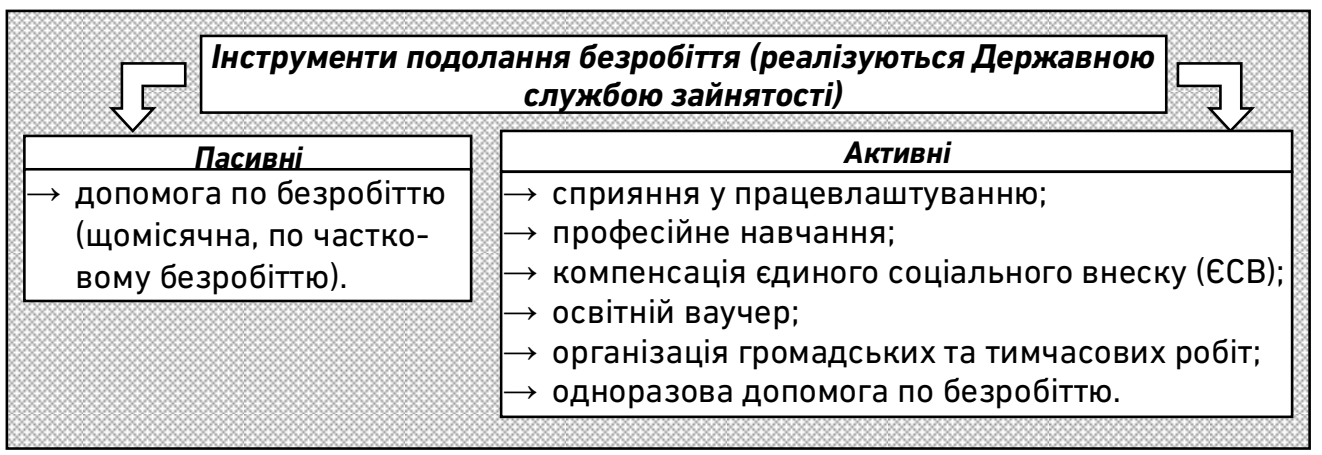

Рис. 3. Інструменти подолання безробіття в Україні, що реалізуються Державною службою зайнятості

Дослідження звітних даних Державної служби зайнятості (табл. 2) свідчить, що протягом 2010-2017 рр. частка безробітних, охоплених активними заходами сприяння зайнятості, з 2013 р. суттєво знизилась. Це відбулось переважно за рахунок зменшення частки працевлаштованих безробітних протягом 2013-2015 рр. Водночас, протягом 2016-2017 рр. рівень працевлаштування безробітних за посередництвом ДСЗ суттєво зріс, сягнувши у 2017 р. 37,9\%. Частка безробітних, залучених до професійного навчання, протягом досліджуваного періоду дещо змінювалася (варіювала в межах від 16,3\% у 2012 р. до 12,5\% у 2015 р.). Рівень залучення безробітних до виконання громадських робіт протягом 2010-2015 рр. суттєво зменшився, хоча з 2016 р. намітилась тенденція до його збільшення.

Показово, що протягом 2010-2017 рр. частка безробітних, охоплених пасивними програмами подолання безробіття, незначно зменшилась та склала у 2017 р. близько $80 \%$.

Очевидно, що частина безробітних одночасно охоплюється як пасивними, так і активними заходами. Зокрема, у 2012 р. близько $70 \%$ безробітних була залучена одночасно в активні та пасивні програми подолання безробіття, в той час як у 2016 та 2017 р. відповідна частка склала лише $47,8 \%$ та $52,4 \%$ (рис. 4 ).

Аналіз кількісних показників залучення безробітних до програм подолання безробіття, доцільно доповнити якісним аналізом. Зокрема, в цілях аналізу дієвості чинної програми виплати ДПБ, доцільно дослідити розмір відповідних виплат. Відповідно до законодавства в Україні встановлюється два види мінімального розміру ДПБ: 1) для застрахованих безробітних, які протягом останніх 12 місяців мають страховий стаж не менше 6 місяців; 2) для незастрахованих осіб або ж тих безробітних, які протягом останніх 12 місяців мають страховий стаж менше 6 місяців. Розмір мінімального розміру ДПБ 
Показники залучення безробітних до активних та пасивних програм подолання безробіття

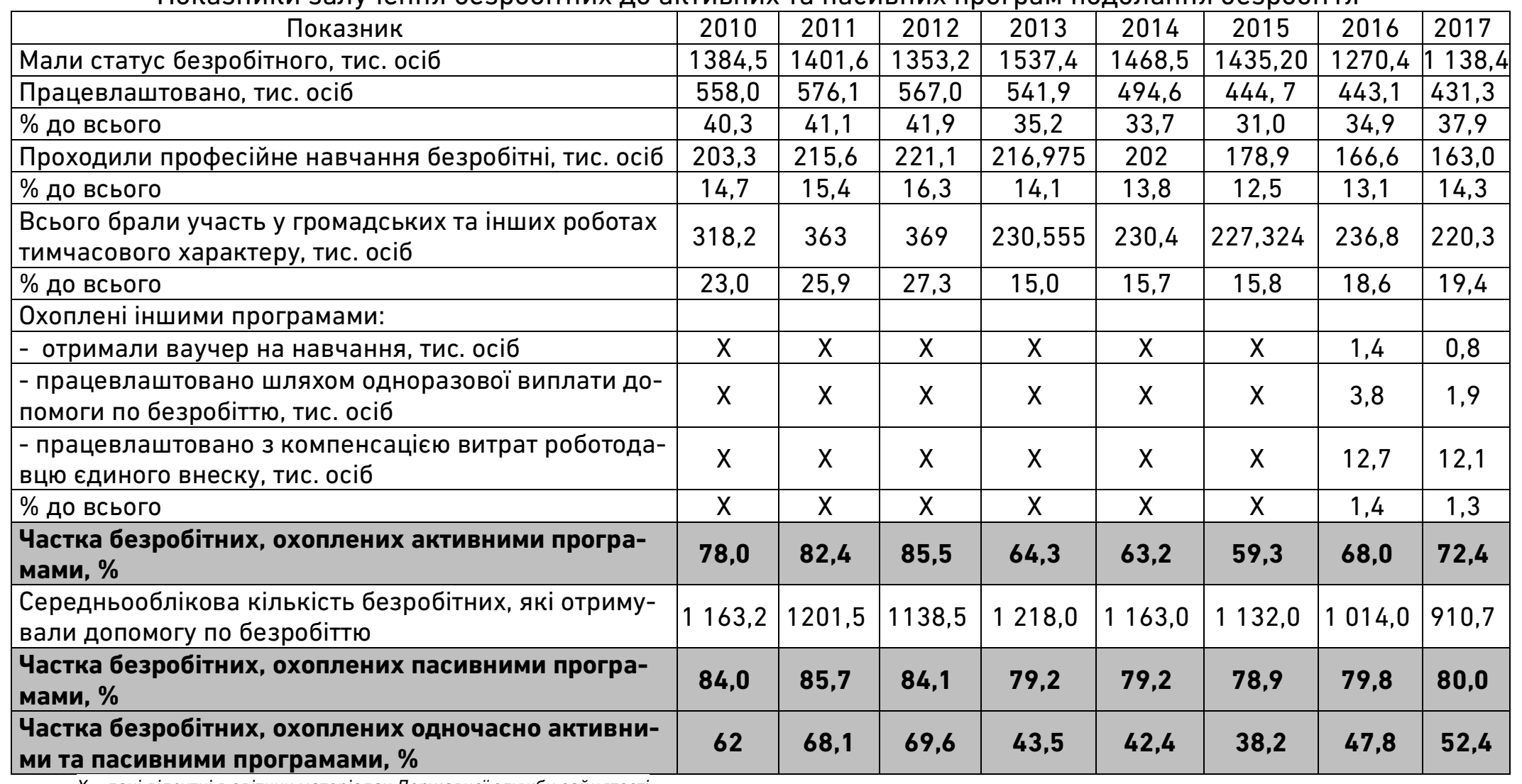

Х-дані відсутні в звітних матеріалах Державної служби зайнятості

Джерело: узагальнено авторами за даними [3] 
встановлюється постановою правління Фонду загальнообов'язкового державного соціального страхування на випадок безробіття. Дослідження динаміки ДПБ в Україні (рис. 5) свідчить, що протягом 20132017 рр. мінімальний розмір ДПБ для незастрахованих осіб та безробітних, страховий стаж яких протягом останніх 12 місяців складає менше 6 місяців, залишався незмінним (544 грн./місяць).

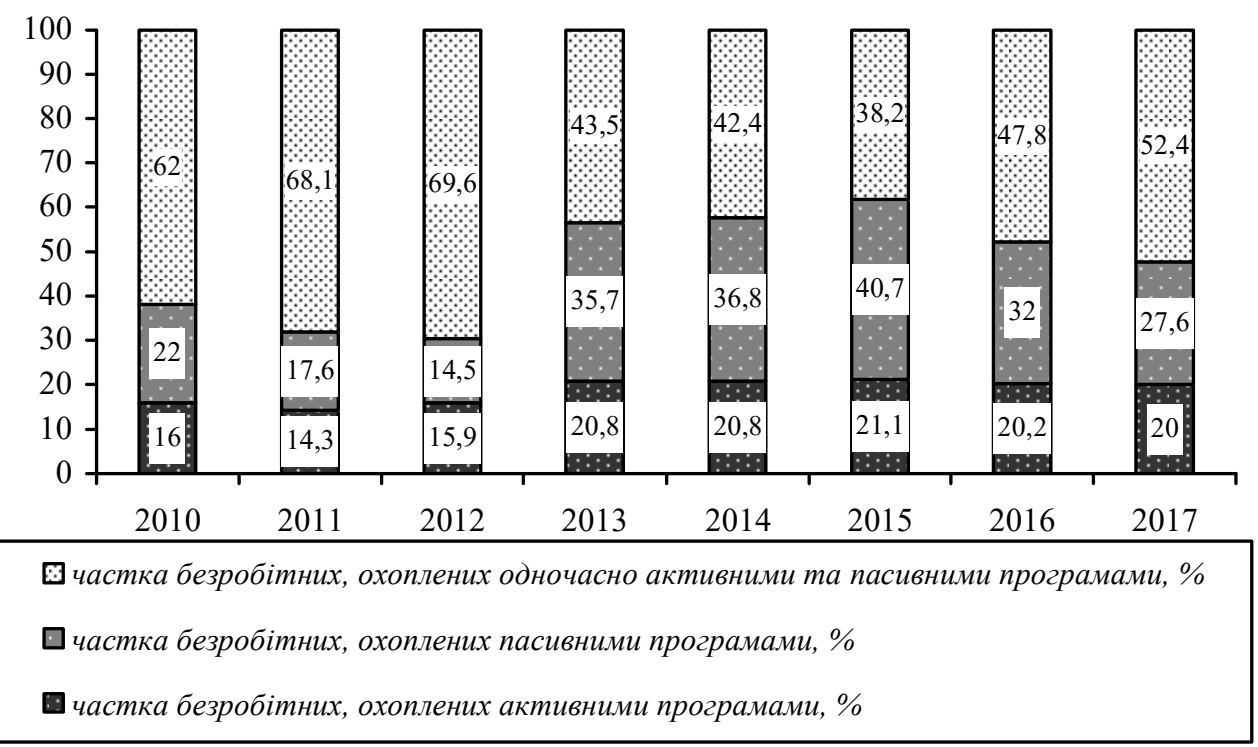

Рис. 4. Частка безробітних, охоплених активними та пасивними програмами сприяння зайнятості (в т.ч. одночасно), \%

Безумовно, така незначна сума на сьогоднішній день не забезпечує належного соціального захисту і підтримки безробітних в період втрати роботи. Вбачається за доцільне щорічно переглядати відповідну суму та корегувати їі з урахуванням динаміки базового соціального стандарту - прожиткового мінімуму.

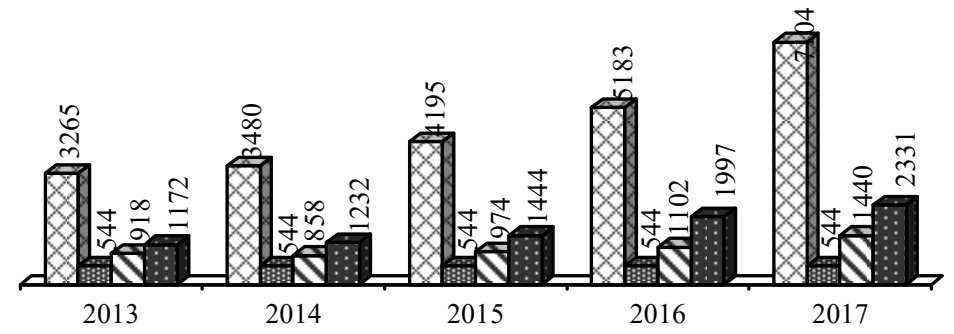

\footnotetext{
Всереднямісячна заробітна плата, грн/місящь

目 мінімальний розмір ДПБ для застрахованих осіб, страховий стаж яких проп останніх 12 місяиів складає менше 6 місяиів, грн./місяиь

$\boldsymbol{\nabla}$ мінімальний розмір ДПБ для незастрахованих осіб та осіб, страховий стаж протягом останніх 12 місяиів складає більше 6 місяиів, грн./місяџь

- середній розмір ДПБ, грн./місяиь
}

Рис. 5. Динаміка допомоги по безробіттю в Україні, 2013-2017рр. [3] 
Попри щорічне збільшення мінімального розміру ДПБ для застрахованих безробітних, страховий стаж яких протягом останніх 12 місяців складає не менше 6 місяців, все ж його розмір не відповідає прожитковому мінімуму для працездатних осіб. Дослідження середнього розміру ДПБ та середньої заробітної плати свідчить про неадекватне співвідношення між ними. Так, протягом 2010-2017 рр. середній розмір ДПБ варіював в межах від 33 до 36\% від середньої заробітної плати. Таким чином, на жаль, можна констатувати, що такий інструмент пасивної політики на ринку праці, як виплата ДПБ, не забезпечує належної підтримки безробітних в період втрати доходу.

Безумовно, пріоритетним напрямом подолання безробіття в системі ДСЗ є працевлаштування безробітних. Однак, на сьогоднішній день ДСЗ сприяє працевлаштування лише кожного третьогочетвертого безробітного. Це в значній мірі обумовлено низьким рівнем оплати праці за заявленими вакансіями. Так, близько $25 \%$ вакантних робочих місць мають рівень оплати праці на рівні мінімальної. В той же час, середній рівень оплати за вакантними робочими місцями, інформацією про які володіє ДСЗ, складає лише 4300 грн./місяць.

Професійне навчання безробітних в системі ДСЗ здійснюється переважно за робітничими професіями, серед яких найбільш популярними є: перукар, тракторист-машиніст, електрогазозварник, кухар, манікюрник, оператор котельні, водій автотранспортних засобів, продавець продовольчих товарів, швачка, адміністратор, кравець та ін. Однак, на жаль, в Україні має місце неповне працевлаштування безробітних після професійного навчання (рівень працевлаштування складає 90-95\%).

Прийнятий у 2013 р. новий Закон України «Про зайнятість населення» запровадив в діяльність ДСЗ принципово інші напрями подолання безробіття, серед яких: компенсація ЄСВ, надання освітнього ваучера. Однак, на разі, рівень охоплення ними безробітних $є$ досить незначним, а їх фінансування здійснюється за залишковим принципом (після виплати ДПБ).

Таким чином, попри наявність досить широкого спектру інструментів для подолання безробіття, більшість з них мають досить низьку ефективність або ж незначне фінансування. Крім того, ДСЗ уповноважена надавати визначений перелік послуг виключно на зареєстрованому ринку праці. Тобто, безробітні, які не зареєстровані в ДСЗ, опиняються поза відповідними програмами. Це актуалізує необхідність дослідження впливу макроекономічних факторів на безробіття населення.

Гіпотеза дослідження полягає в тому, що на рівень безробіття (за методикою МОП) впливають макроекономічні фактори, поміж яких варто виділити динаміку реального ВВП, промислового вироб- 
ництва, реальної заробітної плати, інвестицій в основний капітал, інфляції тощо. Результати кореляційного аналізу свідчать, що найбільший вплив на рівень безробіття поміж обраних факторів (х) чинить показник інвестицій в основний капітал (у \% до ВВП). При цьому відповідний зв'язок є оберненим, тобто збільшення інвестицій зумовлює зменшення рівня безробіття і навпаки.

Таблиця 3

Кореляційний аналіз зв'язку між рівнем безробіття (МОП) та основними показниками макроекономічного розвитку

\begin{tabular}{|c|c|c|c|c|c|c|}
\hline Рік & $\begin{array}{c}\text { Рівень без- } \\
\text { робіття, \% } \\
(Y)\end{array}$ & $\begin{array}{c}\text { Індекс реа- } \\
\text { льного ВВП, } \\
\%(x 1)\end{array}$ & $\begin{array}{l}\text { Індекс реаль- } \\
\text { ної заробітної } \\
\text { плати, \% (x2) }\end{array}$ & \begin{tabular}{|c|} 
Інвестиції в \\
основний ка- \\
пітал, \% до \\
ВВП (х3) \\
\end{tabular} & $\begin{array}{c}\text { Індекс промис- } \\
\text { лового виробни- } \\
\text { цтва, \% до поп. } \\
\text { року (x4) }\end{array}$ & $\begin{array}{c}\text { Індекс спо- } \\
\text { живчих цін, } \\
\text { \% (х5) }\end{array}$ \\
\hline 2007 & 6,4 & 108,2 & 110,3 & 29,6 & 107,1 & 116,6 \\
\hline 2008 & 6,4 & 102,2 & 97 & 27,5 & 107,1 & 122,3 \\
\hline 2009 & 8,8 & 84,9 & 99,1 & 20,4 & 79 & 112,3 \\
\hline 2010 & 8,1 & 104,1 & 110,5 & 16,1 & 112 & 109,1 \\
\hline 2011 & 7,9 & 105,4 & 111 & 17,9 & 108 & 104,6 \\
\hline 2012 & 7,5 & 100,2 & 111 & 18,7 & 99,5 & 99,8 \\
\hline 2013 & 7,2 & 100 & 106,8 & 17,1 & 95,7 & 100,5 \\
\hline 2014 & 9,3 & 93,4 & 86,5 & 13,8 & 89,9 & 124,9 \\
\hline 2015 & 9,1 & 90,2 & 90,1 & 13,7 & 87 & 143,3 \\
\hline 2016 & 9,3 & 102,4 & 106,5 & 15,1 & 102,8 & 112,4 \\
\hline 2017 & 9,5 & 104,9 & 118,9 & 15,03 & 100,4 & 113,7 \\
\hline \multicolumn{2}{|c|}{\begin{tabular}{|c|} 
Коефіцієнт кореля- \\
ції
\end{tabular}} & $-0,451$ & $-0,188$ & $-0,829$ & $-0,486$ & 0,297 \\
\hline
\end{tabular}

Побудова діаграми розсіювання та лінії тренду, які візуалізують зв'язок між рівнем безробіття та інвестиціями в основний капітал, дозволили встановити рівняння регресії, у відповідності з яким приріст інвестицій в основний капітал по відношенню до ВВП на $1 \%$ зумовлює зменшення рівня безробіття на 0,18\% (рис. 6).

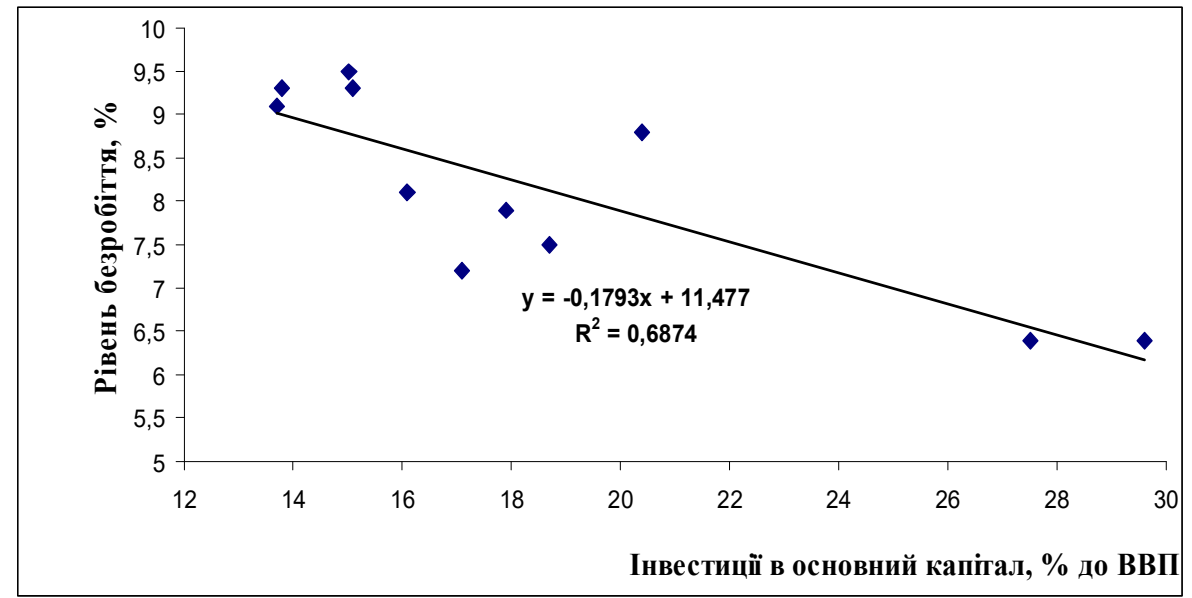

Рис. 6. Лінія тренду та функція регресії між рівнем безробіття та інвестиціями в основний капітал (побудовано за даними 2007-2017рр.) 
Окрім інвестицій в основний капітал, фактором зменшення безробіття $€$ приріст промислового виробництва та реального ВВП.

Кількісно взаємозв'язок між темпами зростання ВВП та рівнем безробіття відповідно до закону Оукена відображає формула (1):

$$
3-\frac{\mathrm{V}_{1}-\mathrm{V}_{0}}{\mathrm{~V}_{0}} \cdot 100=2,7 \cdot \frac{U_{1}-U_{0}}{U_{0}} \cdot 100,
$$

де $V_{1}, V_{0}$ - обсяги реального ВВП відповідно у поточному та базовому періоді; $U_{1}, U_{0}$ - рівні безробіття відповідно у поточному та базисному періоді.

Статистичні дослідження залежності між реальним ВВП та рівнем безробіття засвідчили, що в економіці України дія закону Оукена поки що чітко не простежується (табл. 5). Зокрема, в періоди суттєво зниження реального ВВП (2009, 2014, 2015 роки) відповідно до закону Оукена варто було б очікувати суттєво вищого рівня безробіття (фактичний його рівень був нижчим). В той же час, в періоди значного економічного зростання (2007, 2011, 2017 р.) спостерігається зворотна залежність (рівень безробіття за законом Оукена мав би бути суттєво нижчим у порівнянні з його фактичним рівнем).

Таблиця5

Статистична перевірка закону Оукена на національному ринку праці

\begin{tabular}{|c|c|c|c|c|c|}
\hline \multirow[t]{2}{*}{ Роки } & \multicolumn{2}{|c|}{ Фактичні показники } & \multicolumn{2}{|c|}{$\begin{array}{c}\text { Розрахункові показники } \\
\text { (відповідно до закону Оуке- } \\
\text { на) }\end{array}$} & \multirow{2}{*}{$\begin{array}{c}\text { Відхилення фак- } \\
\text { тичного рівня } \\
\text { безробіття від ро- } \\
\text { зрахункового }\end{array}$} \\
\hline & $\begin{array}{l}\text { Приріст реального } \\
\text { ВВП,\%до поп. року }\end{array}$ & $\begin{array}{c}\text { Рівень без- } \\
\text { робіття, } \%\end{array}$ & $\begin{array}{c}\text { Приріст рівня } \\
\text { безробіття }\end{array}$ & $\begin{array}{c}\text { Рівень без- } \\
\text { робіття }\end{array}$ & \\
\hline 2006 & 7,5 & 6,8 & - & - & - \\
\hline 2007 & 8,2 & 6,4 & $-1,9$ & 4,9 & 1,5 \\
\hline 2008 & 2,2 & 6,4 & 0,3 & 6,7 & $-0,3$ \\
\hline 2009 & $-15,1$ & 8,8 & 6,7 & 13,1 & $-4,3$ \\
\hline 2010 & 4,1 & 8,1 & $-0,4$ & 8,4 & $-0,3$ \\
\hline 2011 & 5,4 & 7,9 & $-0,9$ & 7,2 & 0,7 \\
\hline 2012 & 0,2 & 7,5 & 1,0 & 8,9 & $-1,4$ \\
\hline 2013 & 0 & 7,2 & 1,1 & 8,6 & $-1,4$ \\
\hline 2014 & $-6,6$ & 9,3 & 3,6 & 10,8 & $-1,5$ \\
\hline 2015 & $-9,8$ & 9,1 & 4,7 & 14,0 & $-4,9$ \\
\hline 2016 & 2,4 & 9,3 & 0,2 & 9,3 & 0,0 \\
\hline 2017 & 4,9 & 9,5 & $-0,7$ & 8,6 & 0,9 \\
\hline
\end{tabular}

Тобто, в періоди різкого економічного падіння чи зростання дія закону Оукена в Україні порушується. 3 огляду на це, на жаль, здійснювати макроекономічне прогнозування в Україні на основі закону Оукена не доцільно. Не зважаючи на це, все ж статистична перевірка закону Оукена на національному ринку праці підтверджує обернений зв'язок між реальним ВВП та рівнем безробіття. 
Висновки і пропозиції. Високий рівень безробіття $\epsilon$ негативним соціально-економічним явищем. В Україні рівень безробіття (за методикою МОП) з 2014 р. демонструє стійку тенденцію до зростання, в той час як рівень зареєстрованого безробіття навпаки знижується. В цілях подолання безробіття ДСЗ реалізує комплекс заходів як активного, так і пасивного спрямування. Частка безробітних, охоплених активними заходами сприяння зайнятості, з 2013 р. суттєво зменшилась, в той же час частка безробітних, охоплених пасивними програмами, незначно зменшилась та склала у 2017 р. близько $80 \%$. Виплата допомоги по безробіттю не забезпечує належного соціального захисту та підтримки безробітних, адже мінімальний / середній розмір не відповідає прожитковому мінімуму / середній заробітній платі. $\mathrm{Pi}$ вень працевлаштування безробітних за посередництвом ДСЗ $є$ достатньо низьким з огляду на низький рівень оплати праці за заявленими вакансіями. Професійне навчання безробітних спрямоване на підвищення конкурентоспроможності, а відтак затребуваності безробітних на ринку праці. Рівень охоплення безробітних такими заходами як компенсація $Є C B$, надання освітнього ваучера $€$ досить незначним, а їх фінансування здійснюється за залишковим принципом. Окрім програм подолання безробіття, які реалізує ДСЗ, важливими факторами впливу на безробіття $\epsilon$ макроекономічні, поміж яких визначальним $\epsilon$ інвестиції в основний капітал. Крім того, фактором зниження безробіття $\epsilon$ економічне зростання. Таким чином, ефективна політика держави щодо зниження безробіття потребує комплексного підходу на основі поєднання заходів сприяння зайнятості, які реалізує ДСЗ, та політики стимулювання інвестиційної активності і економічного зростання.

1. Ярова Л. Г. Аналіз рівня безробіття в Україні та напрямки його подолання. Глобальні та національні проблеми економіки. 2015. Вип. 4. С. 752-755. 2. Про зайнятість населення : Закону України від 05.07. 2012 № 5067-VI. 3. Надання послуг населенню та роботодавцям Державною службою зайнятості : статистичні дані. Державна служба зайнятості України. URL: http://www.dcz.gov.ua/. (дата звернення: 15.01.2019). 4. Labor market (Database 2010-2017) / European Commission. Eurostat. [Electronic resource]. - Accessed at: http://ec.europa.eu/eurostat/data/database (дата звернення: 15.01.2019).

\section{REFERENCES:}

1. Yarova L. H. Analiz rivnia bezrobittia v Ukraini ta napriamky yoho podolannia. Hlobalni ta natsionalni problemy ekonomiky. 2015. Vyp. 4. S. 752-755. 2. Pro zainiatist naselennia : Zakonu Ukrainy vid 05.07. 2012 № 5067-VI. 3. Nadannia posluh naselenniu ta robotodavtsiam Derzhavnoiu sluzhboiu zainiatosti : 
statystychni dani. Derzhavna sluzhba zainiatosti Ukrainy. URL: http://www.dcz.gov.ua/. (data zvernennia: 15.01.2019). 4. Labor market (Database 2010-2017) / European Commission. Eurostat. [Electronic resource]. - Accessed at: http://ec.europa.eu/eurostat/data/database (data zvernennia: 15.01.2019).

Рецензент: д.е.н., професор Безтелесна Л. І. (НУВГП)

Yurchyk H. M., Candidate of Economics (Ph.D.), Associate Professor, Chovpylo M. M., Senior Student (National University of Water and Environmental Engineering, Rivne)

\section{TENDENCIES AND DIRECTIONS OF OVERCOMING UNEMPLOYMENT IN UKRAINE}

The purpose of this article is a comprehensive study of unemployment trends and ways of overcoming it in Ukraine in order to identify the main problems and substantiate proposals in the relevant field. The trends of unemployment in Ukraine are investigated. The analysis of attraction of unemployed to active and passive programs in the system of the State Employment Service was conducted. The influence of macroeconomic factors on unemployment of population is proved. The basic problems and directions of decrease of unemployment in Ukraine are determined.

Keywords: unemployment, unemployment rate, unemployment benefit.

Юрчик Г. Н., к.э.н., доцент, Човпыло М. Н., студент (Национальный университет водного хозяйства и природопользования, г. Ровно)

\section{ТЕНДЕНЦИИ И НАПРАВЛЕНИЯ ПРЕОДОЛЕНИЯ БЕЗРАБОТИЦЫ В УКРАИНЕ}

Исследована тенденции безработицы в Украине. Проведен анализ привлечения безработных к активным и пассивным програмам в системе Государственной службы занятости. Доказано влияние макроэкономических факторов на безработицу населения. Определены основные проблемы и направления снижения безработицы в Украине.

Ключевые слова: безработица, уровень безработицы, пособие по безработице. 